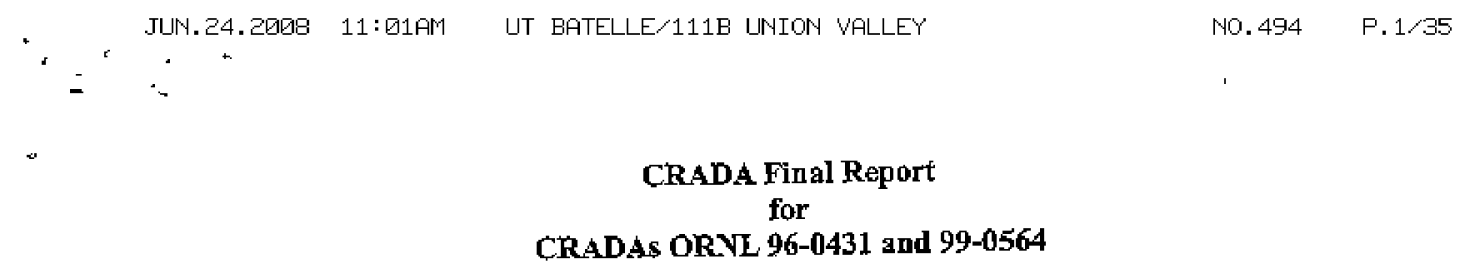

\title{
Intelligent Machine Learning Analysis For Fuel Cell Operations
}

\author{
R. W. Murphy \\ Oak Ridge National Laboratory \\ Oak Ridge, Tennessee \\ and \\ W. A. Hoyt \\ ERC, Inc. \\ Huntsville, Alabana
}

Jume 30,2000

\section{PROTECTED CRADA INFORMATION}

This product contains protected CRADA worormation (Tabeled as PCIs in the text) which was produced on June 30, 2000 under CRADAs No. 96-0431 and 99-0564 and is not to be further disclosed for a period of five (5) years from the date it was produced except as expressly provided for in the CRADA 


\section{List of Figures}

Fig. 1. Isometric Drapring of the $100 \mathrm{~kW}$ Power System.

Fig. 2. Flow Chart for $100 \mathrm{~kW}$ Solid Oxide Fuel Cell Generator System Model.

Fig. 3. Layout of the $100 \mathrm{sW}$ Stack.

Fig. 4. Cell Voltage Versus Current Density at $1000^{\circ} \mathrm{C}$.

Fig. 5. Segment Voltage Versus Current at $1000^{\circ} \mathrm{C}$.

Fig. 6. Stack Voltage Versus Current at $1000^{\circ} \mathrm{C}$.

Fig. 7. Gross Stack Power Versos Current at $1000^{\circ} \mathrm{C}$.

Fig. 8. Generator Natural Gas Flow Versus Current (EDB/ELSAM).

Fig. 9. Generator Natural Gas Flow Versus Current (PNG/WESTC).

Fig. 10. Natural Gas Nozzle Pressure Versus Current (EDB/ELSAM).

Fig. 11. Natural Gas Nozzle Pressure Versus Cument (PNGMESTC).

Fig. 12. LHV Cell Electrical Efficiency Versus Current.

Fig. 13. HFV Cell Electrical Efficiency Versus Current.

Fig. 14. Air lnlet 'Temperature Versus Current.

Fig. 15. Generator Process Air Flow Versus Current.

Fig. 16. Steam Flow Versus Current.

Fig. 17. Single Operating Point Display.

Program Listing

Input File Listings 
TNTELLIGENT MACHINE LEARNTSG ANALYSIS FOR FUEL CELL OPERATIONS: SOLTD OXIDE FUEL CELL GENERATOR SYSTEM MODEI

\section{ABSTRAC'l'}

A performance computational model for a $100 \mathrm{~kW}$ nominal solid oxide fuel cell gqnerator system is described. The calculational methods are based on the FORTRAN programming language. Comprehensive parameter input options are presented, and constraints are identified. Example reactant, electrical, and efficiency outputs are demonsirated over the rele rant operating ranges. A sample calculated ontput display at nominal operating conditions is given. 


\section{BACKGROUND}

The relatively high operating temperatures $\left(600-1100^{\circ} \mathrm{C}\right)$ of solid oxide fuel cells offer the promises of intemal refoming (elimination of external refonner component) of natural gas fuel, rapid kinetics (without the inwolvement of precious materials), immunity to "poisons" (carbon monoxide actualiy serves as a fuel), and high quality product heat for bottoming cycle andior valuable process use, but offer substantial challenges regarding constuction materials and control requirements (Ref. 1). Performance models can assist in exercising and evaluating selected control options.

\section{MODEL DEYELOPMENT}

A FORTRAN language-based model of performance for a $100 \mathrm{~kW}$ nominal solid oxide fuel cell generator system (illustrated in Fig. 1) was developed. The model characterizes setpoints, controls, and outputs of the system for selected fuels, operational states, and operator inputs within identified envelope limits. The main program accesses system limit information stored in an ASCI file named ICNITS.DAT and operator input information stored in a separate ASCI file named OPDNUT.DAT to avoid the necessity of recompiling the main FORTRAN file each time a change in limit or operator input parameters is desired. A description of the details of the model is presented below. Figure 2 shows a model flow chant for convenient reference. The remaining figures show sample relationships between parameters caloulated by the model and operating climents for selected values of other operator inputs.

\section{INPUTS}

\section{Cell Stack and Geometry}

The generator module is comprised of a "stack" or array of 1152 individual tubular solid oxide fulel cells as shown in Fig. 3. They are arranged as 12 strings (of 96 cells each) series-conmected in a serpentine configuration with one air-cooled power lead at each end for direct-curent power takeoff. Each string consists of 2 segments (of 48 cells each) also connected in series. Each segment consists of 2 bundles (of 24 cells each) again connected in series. As the fundamental building block of the module, a bundle has 3 parallel current paths (circuits) formed from 3 rows of 8 series-connected cells each. Each cell has a length of $150 \mathrm{~cm}$ and an outside diameter of $2.22 \mathrm{~cm}$. The module arrangement provides fuel to the outside of each tubular cell and air to the inside. Thus the outside electrode serves as the anode by producing electrons for the external power conmection while the inside electrode serves as the cathode by accepting electrons from the extermal power connection. The oxygen ions are conducted through each cell's solid oxide electrolyte with an effective conduotion area of $810 \mathrm{~cm}^{2}$.

\section{Fuel Characteristies}

The primary fuel supply for the generator system is natural gas. The composition of this fuel is subject to change both as a function of time (for example, summer low demand versus winter pealing) and location [for example, the Westinghouse (PNGMESTC) location in the United 


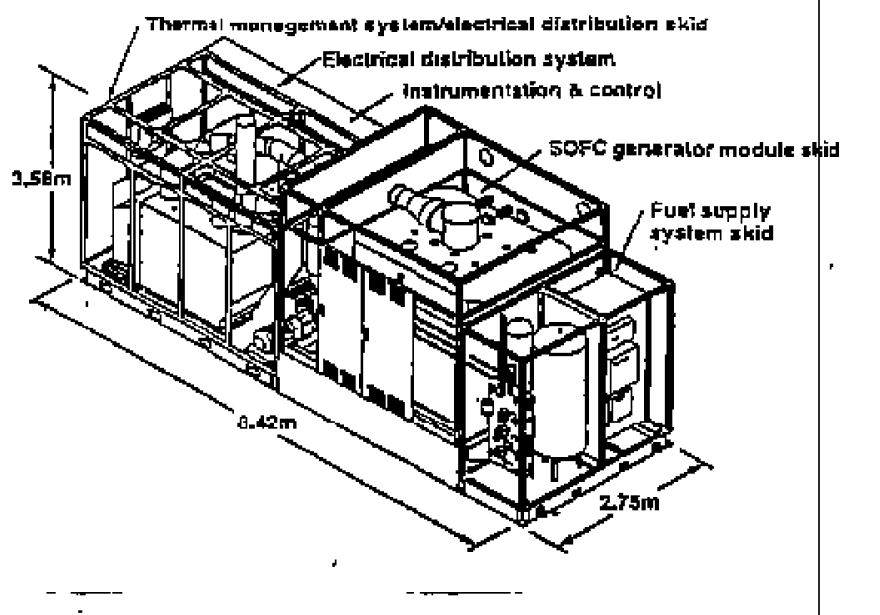

Fig. 1. Isometic Drawing of the $100 \mathrm{~kW}$ Power System.

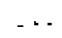

5 (PCI) 


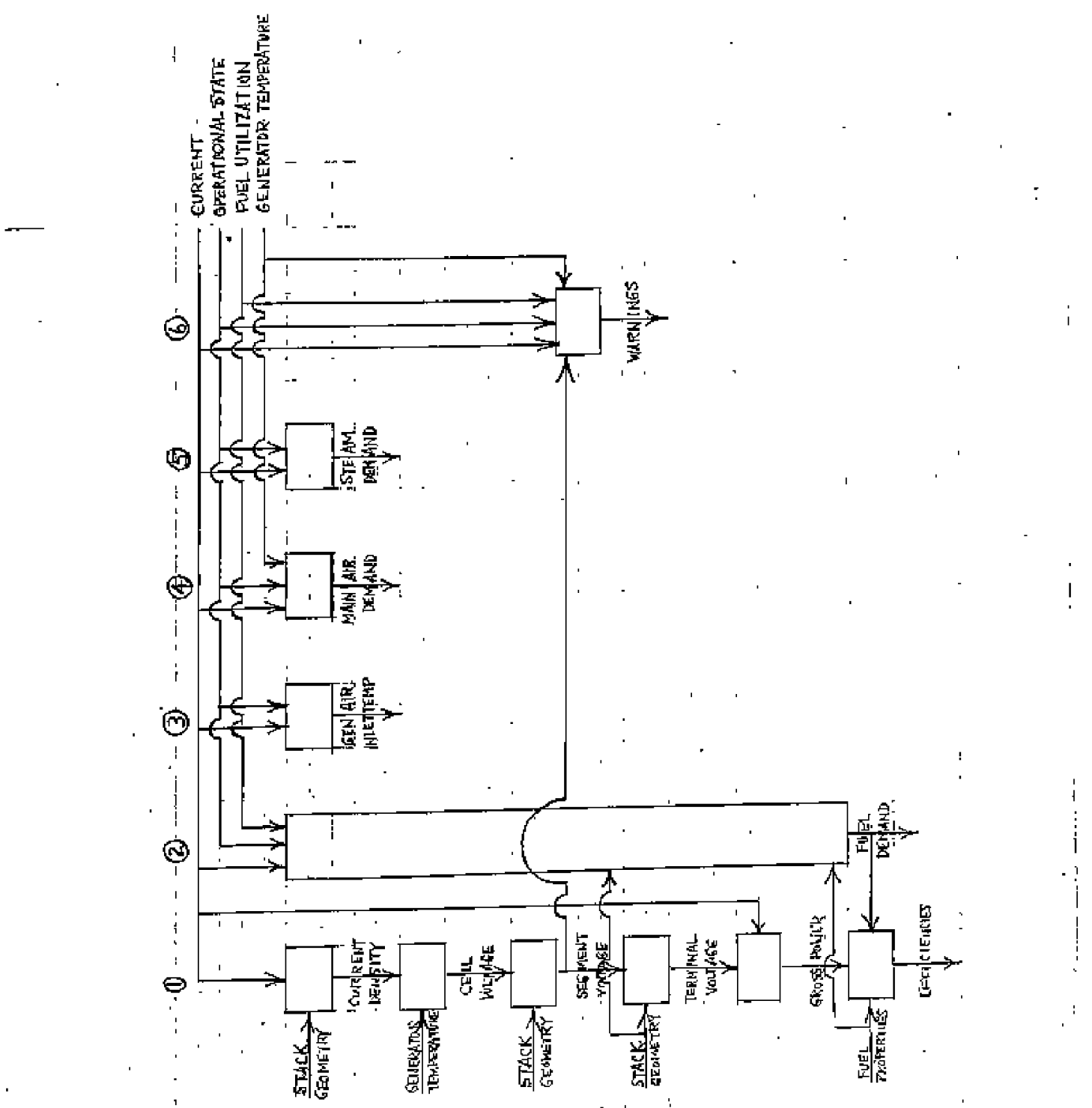

Fig, 2. Flow Chart for $100 \mathrm{~kW}$ Solid Oxide Fuel Cell Generator System Model. 


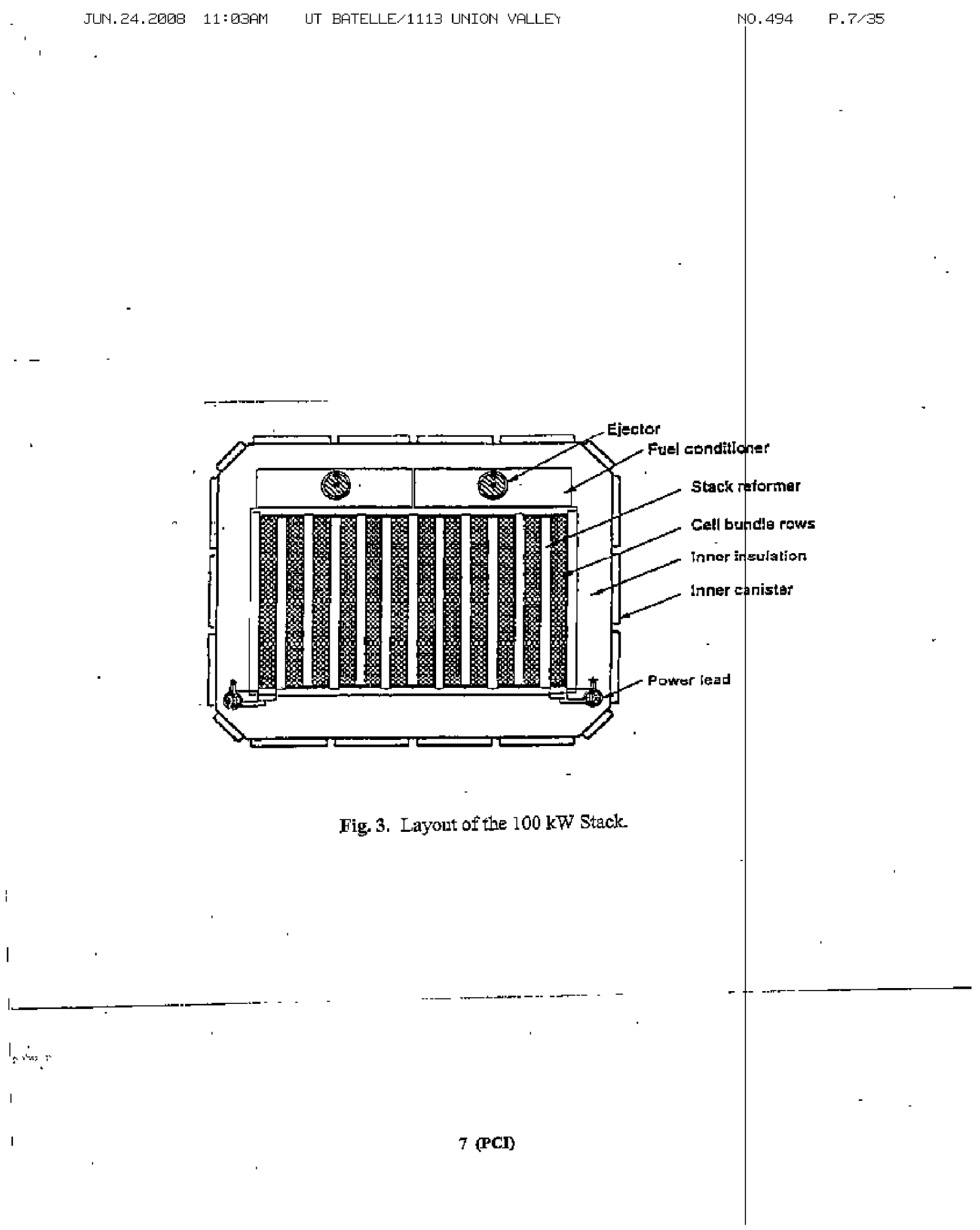


States versus the Nuon (EDBIELSAM) location in the Netherlands]. In principle, the solid oxide fuel cell is capable of operation with hydrogen, hydrocarbon, or carbon monoxide fuel. However, with matural gas, the main constituent of the fiel is methane, with small fractions of higher bydrowarbons (ethane, propane, butame, etc.) lso being present. For present purposes, mixed hydrocarbon ficel is chamactenzed by the average number of moles of reformed fucl (hydrogen and carbon monoxide) produced from each mole of unreformed fuel. If the urreformed fuel contained only methane, the relevant value would be 4 . For the PINGNWESTC location, this value is taken to be 4.056. For the EDB/ELSAM location, the conesponding value is 3.5606 . Related fuel properties include effective molecular weight and heating values (lower and higher).

\section{Generator Temperature}

The generator terperature is an operator input intended to achieve and maintain the cell electrolyte at a temperature that can provide the required oxygen ion conductivity, subject to other constraints. At steady state, this temperature is the result of achicring a bilatice between the heat produced within the generator and the heat removed from it. In practice, control is acomplished by varying bypass air flow around one low and one high temperature recuperator and/or by varying electrical powwer input to one on/off air heater $(100 \mathrm{~kW})$ and one modulating air heater ( $100 \mathrm{~kW}$ max). Nomally, heater power is not required when the generator is operating above the "themal sustain boundary," estimated to occur at a generator current of approximately $407 \mathrm{~A}$. The generator temperature also determines whether or not specific operafional states are permitted. For present purposes, cell performance data was available in Ref. 2 only for an operating tenperature of $1000^{\circ} \mathrm{C}$.

\section{Fuel Utilization}

The fucl utilization increment is an operator input intendeat to control the excess amount of fuel (above that required stoichiometrically for a given curent) supplied to the generator. The baseline fuel utilization has been established by the manufacturer to be $85 \%$. At an earlier point, the allowed increment range about this baseline was $-3 \%$ to $+5 \%$, giving a net fuel utilization range of $82 \%$ to $90 \%$. Later changes increased the allowed inerement range to $-3 \%$ to $+5 \%$, giving a net fuel ufiflization range of $77 \%$ to $90 \%$. For operation in the RUN opefational state, fuel utilization is one of the parameters used in the algorithm for deternine the desired finel flow setting.

\section{Current}

The current is an operator input that acts as the prinary parameter for determining fuel flow, gteam flow, air flow, and air inlet temperature setpoints for the generator. Together with the cell stack georietry, the cument determines the current density, which, in turn, establishes the cell, segment, and terminal woltages of the stack, as well as, ultimately, the gross stace (direct current) power. 


\section{Operational State}

The operational state is an operator input that establishes, within constraitsts, the generator functional mode. The valid states are PRE-OP, HEAT, LOAD, RUN, STOP, COQL, SAFESTOP. Allowable operation in a particular state or change frow one state to another is predicated on satisfaction of selected constraints concerning generator temperatura, current, segment voltage, efe. In the model, detailed consideration is linited to the LOAD and RUN states because they are the only normal functional modes in which the generator is producing electrical power.

\section{ALGORITHMS, MODELING, AND OUTPUTS}

\section{Current Density, Voltages, and Gross Power}

As indicated in the first vertival leg of Fig. 2, first the effective generafer eurrent density is determined from the current and the cell stack geometry. Next the cell voltage is determitred fom the calculated current density and the generator temperature, bess on the cell voltage/current density characteristic applicable to the particular generator tempenature (Fig. 4 based on Ref. 2). The decrease of cell voltage with increasing current density reflets polarization and other losses characteristic of this type of fuel cell (Ref.1). The comesponding segment (Fig. 5) and terminal (Fig, 6 ) voltages are caleulated it the model from the cell voltage and the cell stack geometry. Established minimum segment voltages are shown in Fig, 5 and checked as indicated in the section on warmings. Established RUN and LOAD state current limitg are shown in Figs. 5 and 6 and also checked as indicated in the section on marnings. Next the gross stack power (Fig. 7) is calculated from the teminal voltage and the curnent. The nonlinearity of the line in Fig. 7 again reflects characteristic lnsege-

\section{Fuel Flow and Nozzle Pressare}

As shown in the second vertical leg of Fig. 2, the fuel demand (Figs. 8-9) and the corresponding nozzle pressure (Pigs. 10-11) are calculated from algorithms using fuel utilization, operational state, and current operator inputs, as well as cell stack geometry informaliur. The first leg of the model then uses this result along with fuel properties and gross power to calculate lower (Fig. 12) and higher heating value (Fig. 13) gross electric efficiencies.

The model first calculates the reformed (hydrogen or carbon monoxide) fuel flow in standard liters per minute required to suppent a current of 1 A generated by one cell. This value is then multiplied by the total generator current and divided by the total number of patall l circuits (presently 3 ) to detemine the reformed fuiel flow for one cell at its effective operating current. To this anount a fixed correction for each cell is added (from Ref. 2, currently se at 46 standard cubic centimeters per mimute; earlier values fanged from 18 to 21 standard cubic pentimeters por rrimite) to account for apparent leakgge effects. This combined amount is then moltiplied by the total number of cells in the array w detemined the total reformed fuel flots requited by the generator at the operating current. This result is then divided by the appropriate average mumber of moles of hydrogen and carbon monoxide produced from each mole of unreformed fuel 


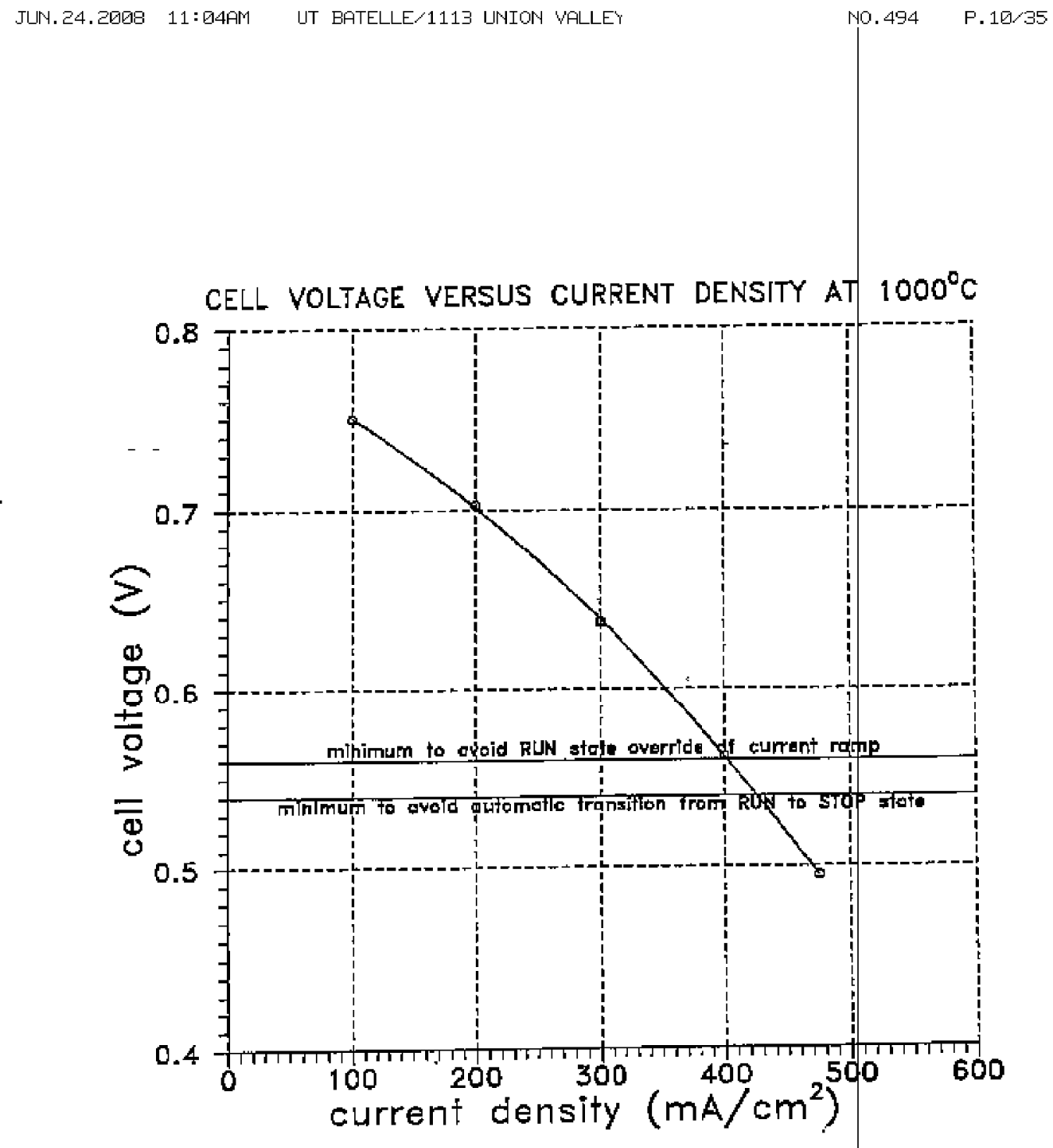

Fig. 4. Cell Voltage Versus Current Density at $1000^{\circ} \mathrm{C}$,

10 (PCD) 


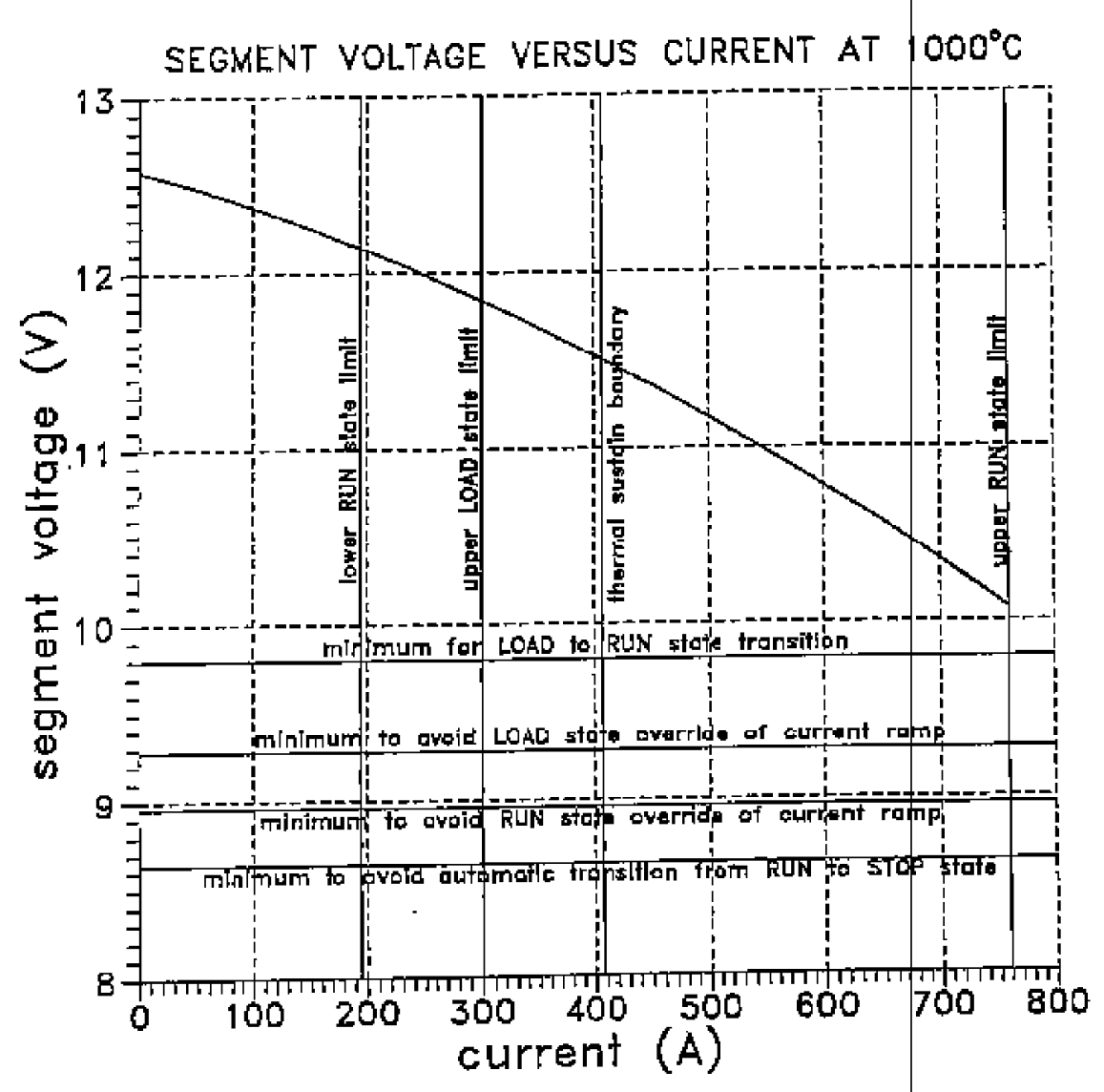

Fig. 5. Segnent Voltage Versus Current at $1000^{\circ} \mathrm{C}$.

11 (PCI) 
JUN.24.2018 11: オ4AM UT BATELLE/1113 UNION VALLEY $\quad$ NO.494 P.12/35

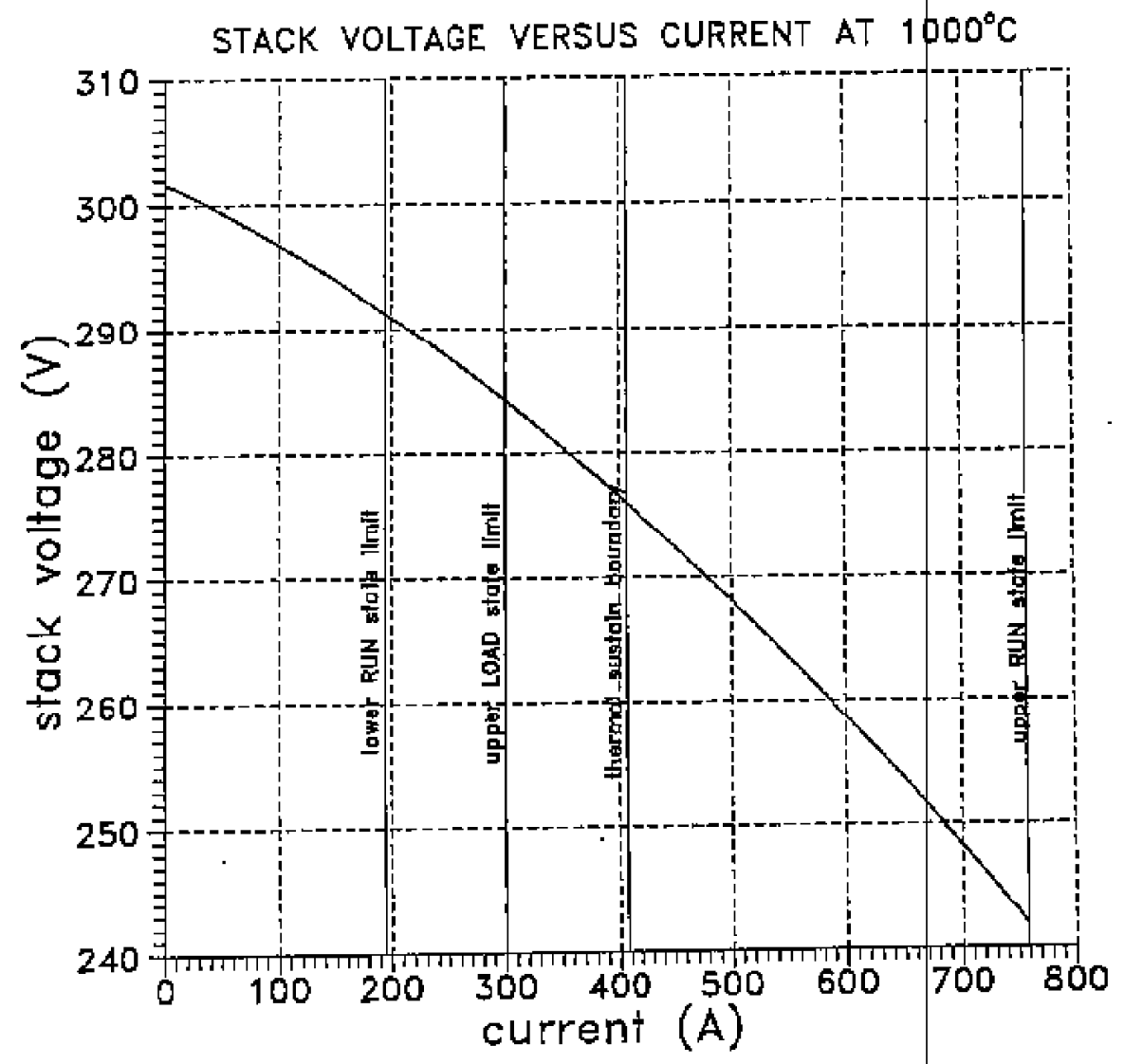

Fig. 6. Stack Voltage Versus Current at $1000^{\circ} \mathrm{C}$.

12 (PCD) 


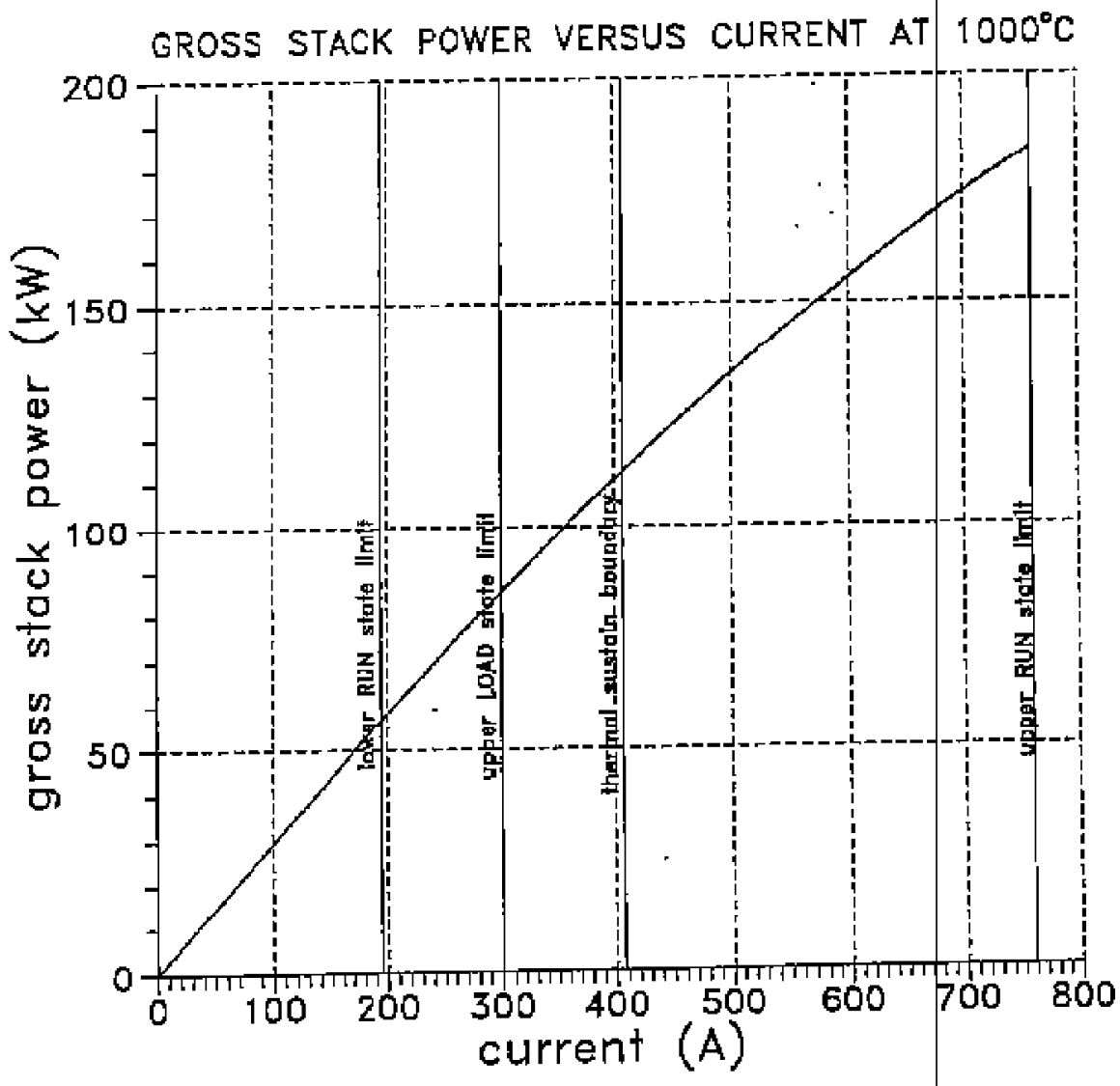

Fig. 7. Gross Stack Power Versus Curent at $1000^{\circ} \mathrm{C}$.

$13(\mathrm{PCI})$ 


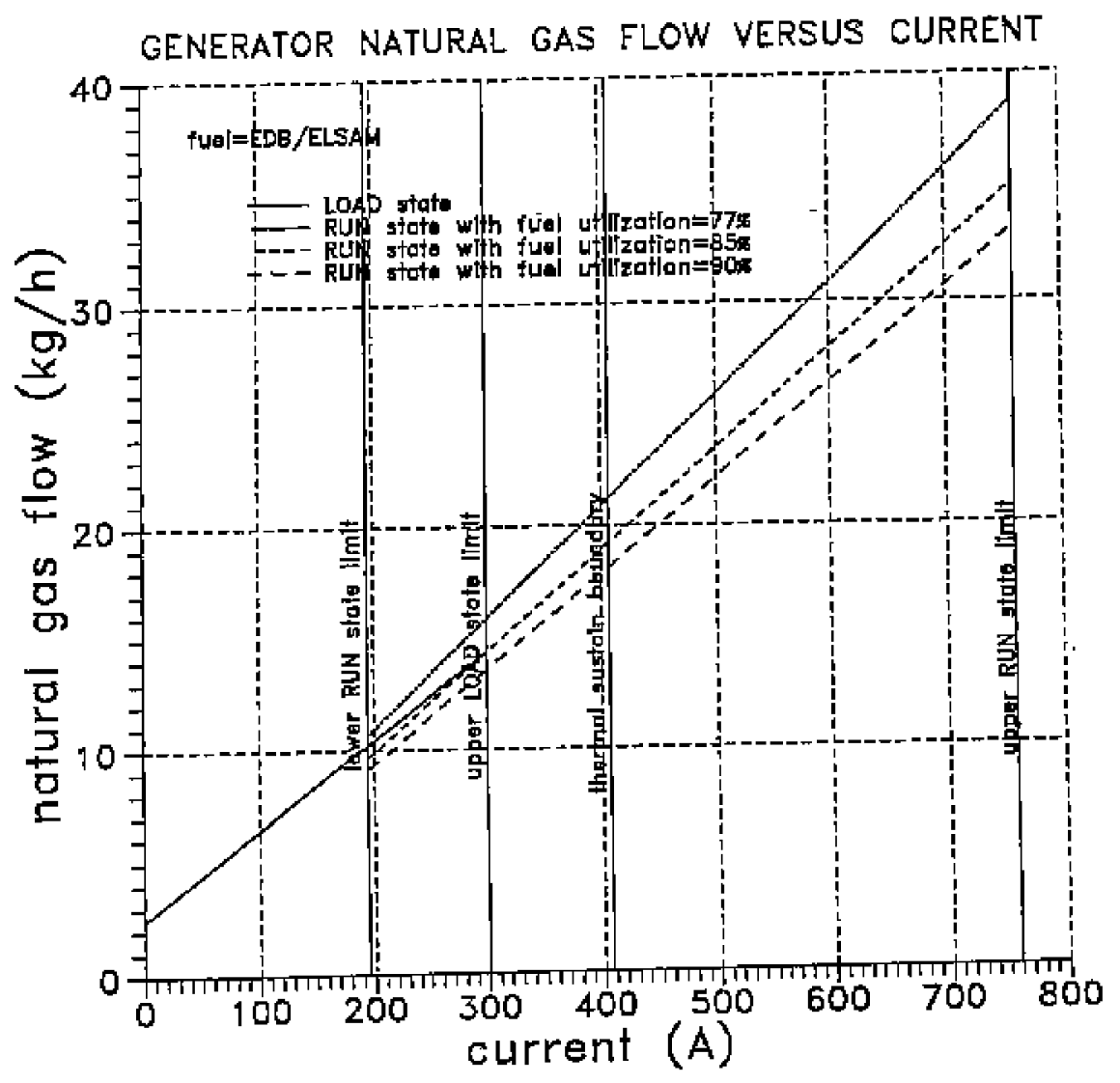

Fig. 8. Generator Natural Gas Flow Versus Current (EDB/ELSAM). 


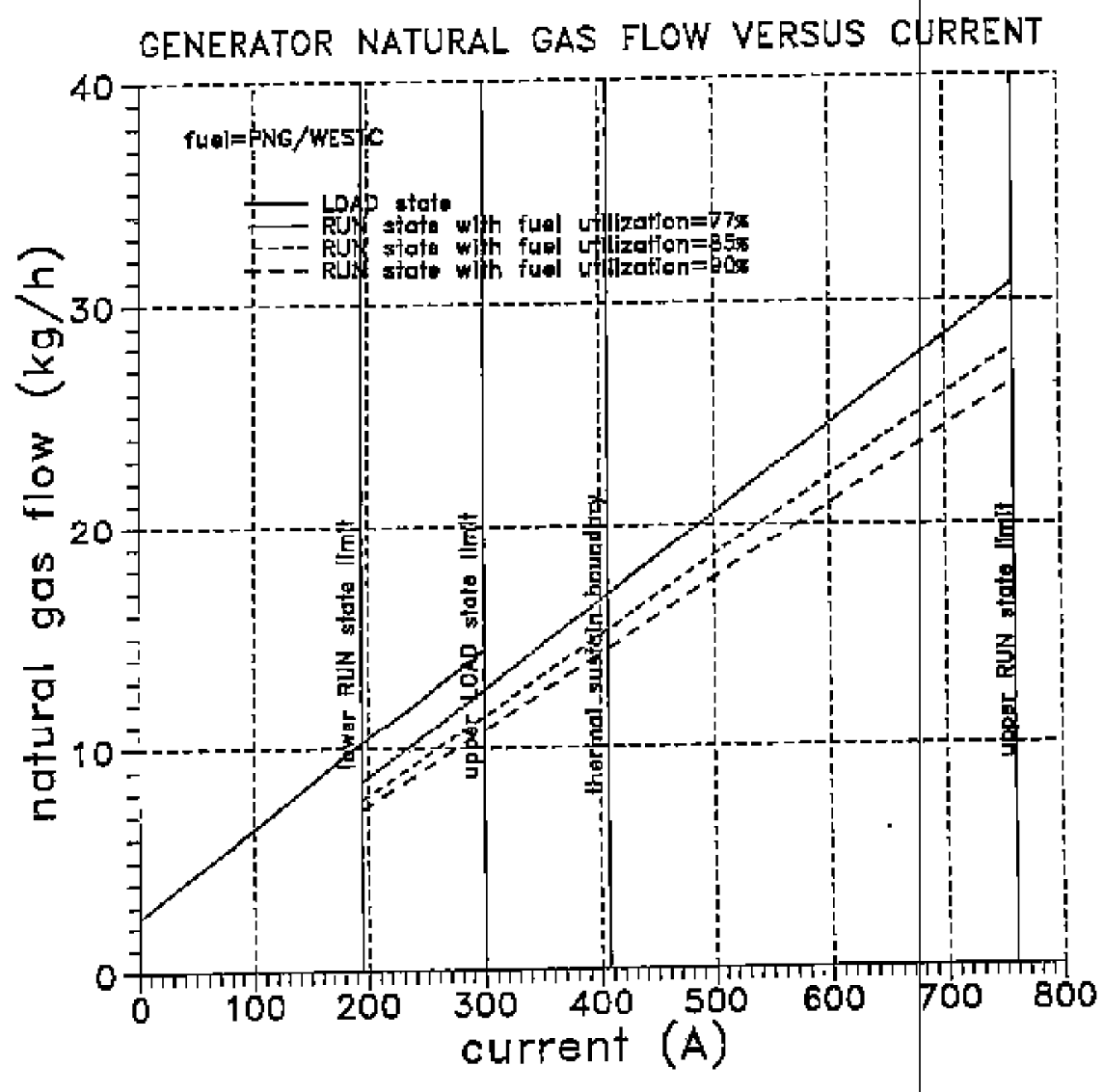

Fig. 9. Generator Natural Gas Flow Versus Current (PNGWESTC).

15 (PCD) 


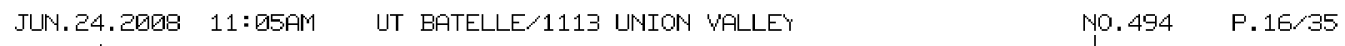

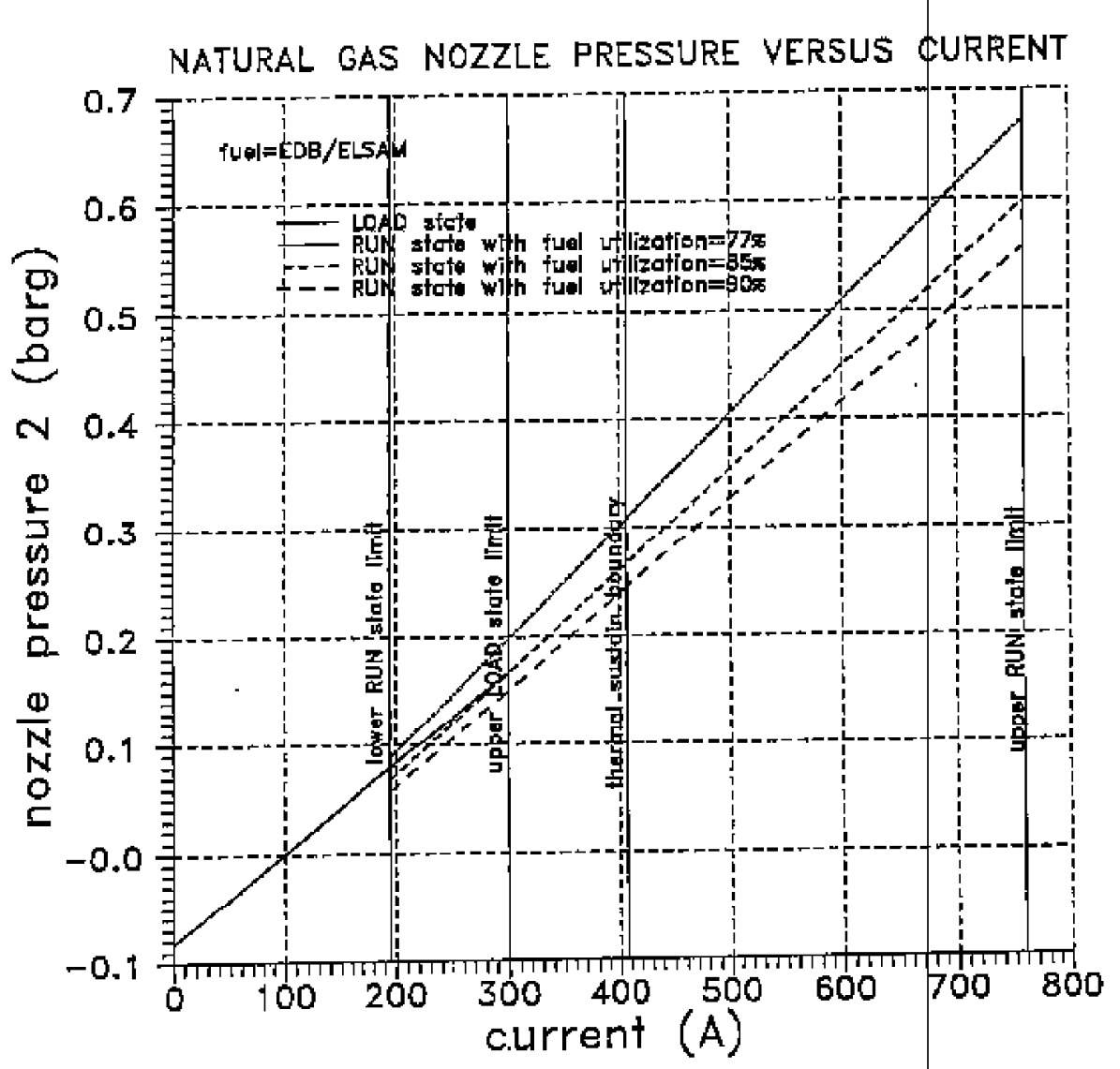

Fig. 10. Natural Gas Nozzle Pressure Versus Current (EDB/ELSAMp.

$16(\mathrm{PCD})$ 


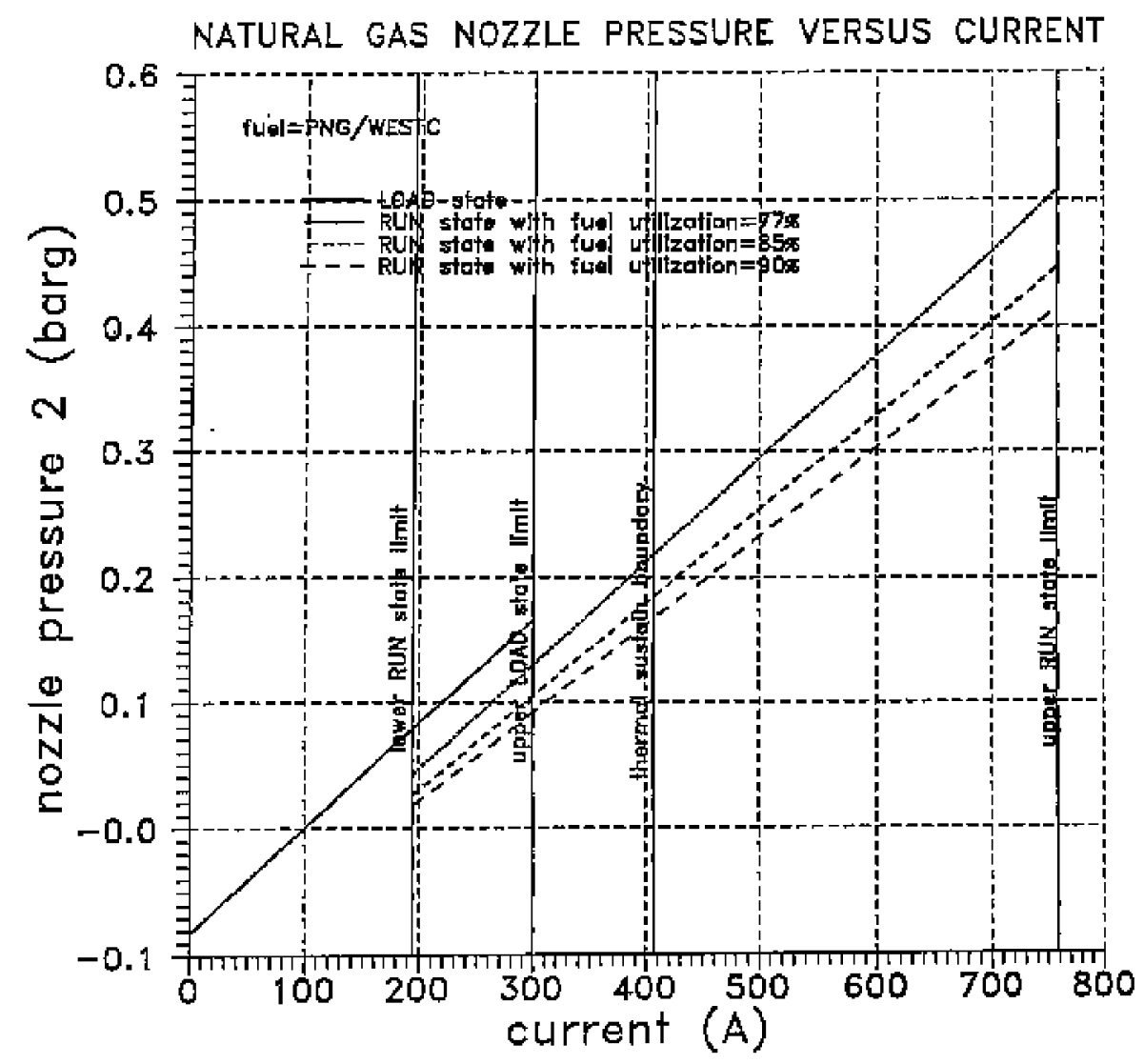

Fig. 11. Natural Gas Nozzle Pressure Versus Current (PNG/WESTC). . 


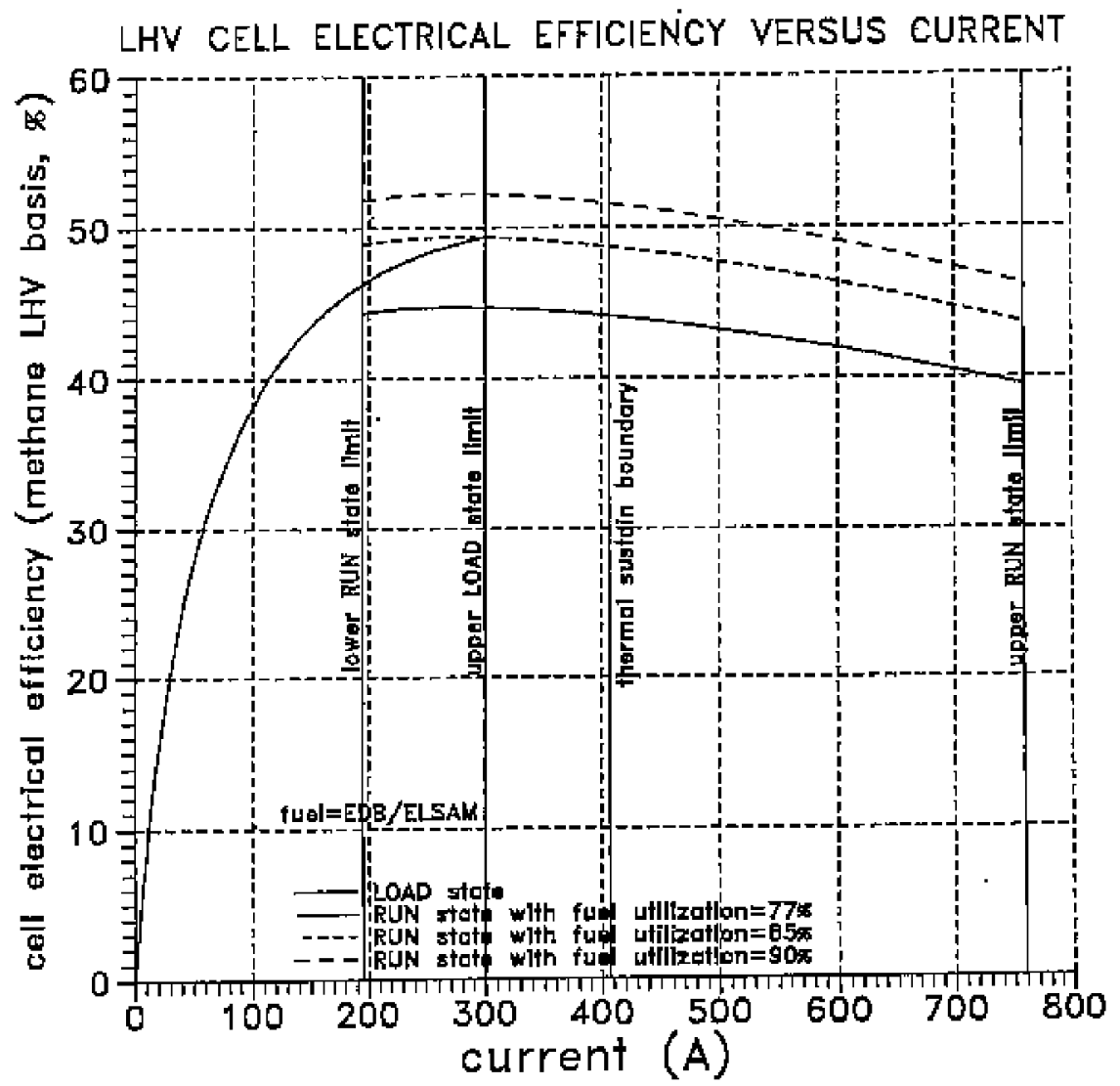

Fig. 12. LFV CeI Electical Efficiency Versus Current. 
HHV CELL ELECTRICAL EFFICIENCY VERSUS CURRENT

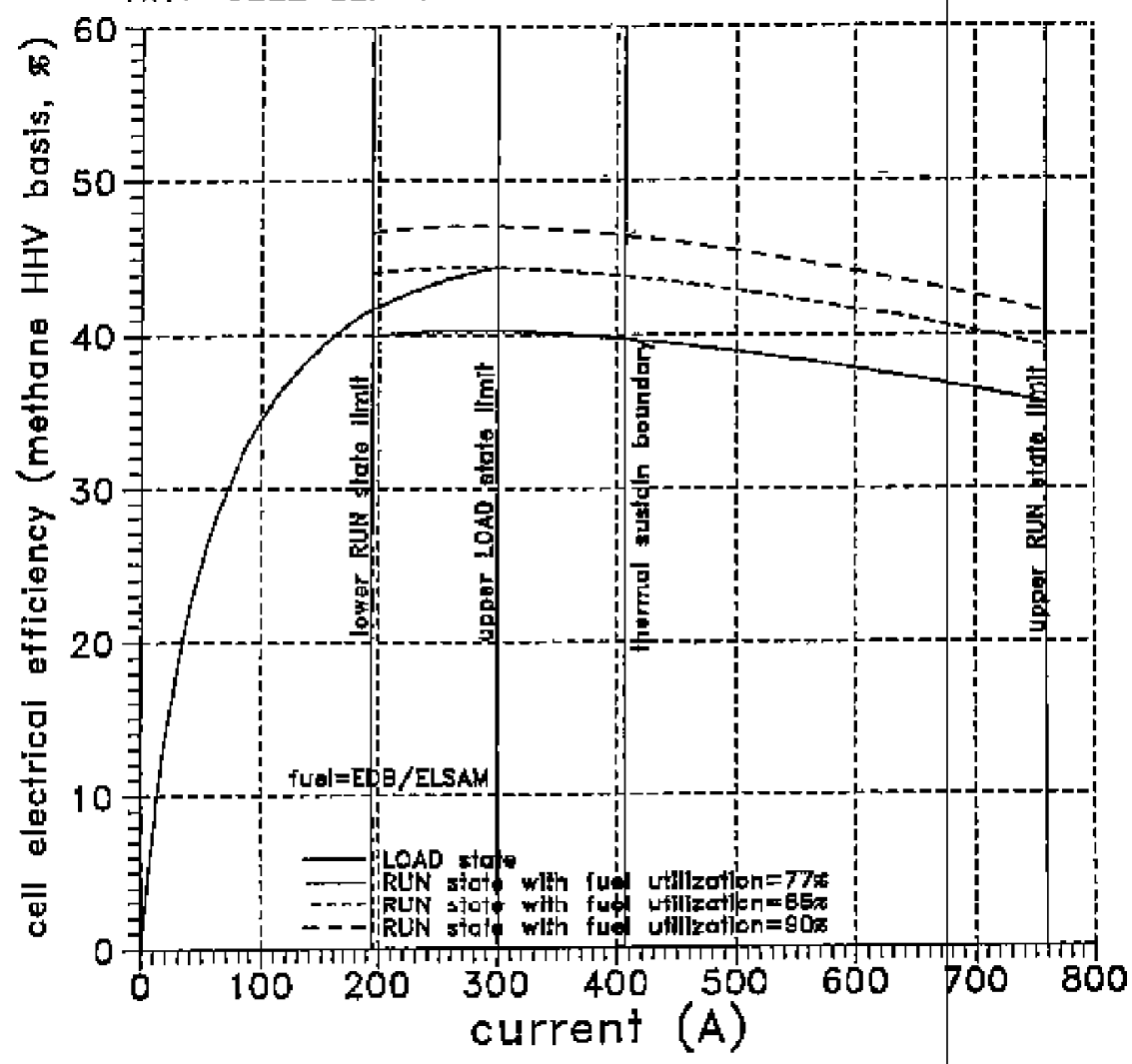

Fig. 13. HHV Cell Electrical Efficiency Versus Current.

19 (PCI) 
(natural gas) to give the unrefomed fuel flow in standard liters per minute required if the generator operated at $100 \%$ fuel utilization. This value is divided by the fuel utilization and a correction factor (Ref. 2) to give the required unrefomed finel flow in standard liters per minute. Then from the unrefomed fuel molecular weight, the related standard density in grams per standard liter is calculated. The plevious result is thon multiplied by this result to give the required unrefomed fol flow in grams per minute, which is then converted to the desired setpoint units of kilograms per hour.

For the IOAD operational state, the algorithm is a similar but slightly different linear relation between firel setpoint and current.

Figure 8 shows the results for EDB/ELSAM fuel in both RUN and LOAD operatipnal states over the fill projected edrrent operating range. As shown in both Fig. 8 and the LMMTS.DAT file Listing allowable currents are presently limited to values less than $300 \mathrm{~A}$ in the LOAD operational state. For the RUN operational state, allowable currents presently range from $195 \mathrm{~A}$ to $759 \mathrm{~A}$. The implied dependence of RUN state setpoint valueg on fuel utilization is also shown using the base, mininum, and maximum levels. Of course, higher fuel utilization corresponds to lower fuel flow for a given ourrent.

Figure 9 shows telated results for PNG/WESTC fuel in the same operational states and oument range. The LOAD state characteristic is identical to that in Fig. 8 because the relevant algorithrn depends only on the operating curent. Howrever, the RUTV state characteristics ar lower thin the corresponding ones in Fig. 8 because of its algorthm"s dependence on the particular fuel composition Specifically, referring to the parameters supplied earlier, one mole of unreformed PNG/WESTC fuel is calculated to provide 4.056 total moles of bydrogen and carbon monoxide when reformed, while one mole of unreformed EDB/ELSAM fuel will provide only 3.5606 .

Far present purposes, the bypass flow around the primary nozzle of the exhanst rifcirculation ejector is closed. In this situation, all the fuel flows through the primary nozzle, and the model employs an algorithm to relate the primary nozzle pressure to the fuel flow. This relationship, with nozzle pressure expressed in bar gauge units is illustrated in Fig. I0 for EDE/ELSAM fuel and in Fig. 11 for the PNG/WESTC fuel.

To calculate the gross electric efficiency of the generator, the model calculates the ratio of the gross stack power determined earlier to the effective beating value of the furel supplied to the generator. For the EDB/ELSAM fuel composition, the lower heating value efficiencies are presented in Fig. I2 and the higher heating value efficiencies in Fig. 13 for both $f O A D$ and RUN operational modes and for RUN fuel utilization value corresponding to the pase, minimum, and maximum levels. The use of the lower heating value basis gives higher appafent efficiencies because it does not account for the beating value associated with condensing water wapor formed during the reaction process. Also, higher fuel utilization implies less fuel flow for a given power, resulting in higher efficiency. The apparent efficiency maxima indicated it the moderate current range are the result of a combination of inberent loss mecharisms. As current increases, the polarization and other losses, illustrated by the voltage decrease with increasing current density in Fig. 4, reduce the effrciency. However, as ourent (and, therefore, fuel flow) 
decreases, the relative importance of the fixed fuel leakage loss increases, thus decreasing effificiency.

\section{Air Inlet Temperature}

As indicated in the third vertical leg of Fig. 2, the generator inlet air temperature setpoint is calculated from aigorithms employing operational state and current operator inputs. In the LOAD operational state, the generator iflet air temperature setpoint is fixed at $735^{\circ} \mathrm{C}$. The same is true for the RUN operational state when the operating current is less than or equal to $300 \mathrm{~A}$. As cuments increase above $300 \mathrm{~A}$ in the RUN operational state, the generator inlet air

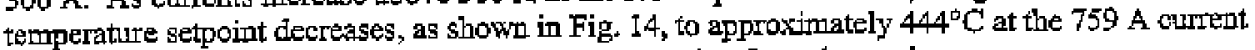
limit to accommodate, in part, the greater heat generation from the stack.

\section{Process Air Supply}

As shown in the fourth vertical leg of Fig. 2, the main air dernand setpoint (Fig. 15) is calculated from algorithms using generator temperature, operational state, and current operator inputs. In the LOAD operational state, with no current the main air blower demand is set at the HEAT operational fixed value of $88.0 \%$. As cument increases in this state, the main air blower denand decreases linearly until it reaches $72.0 \%$ at an operating current of $300 \mathrm{~A}$, the upper LOAD state current limit as shown in Fig. 15. Within the RUN operational state, the algorithm incorporates a proportional integral derivative (PD) control component to assist in controlling the generator temperature. The value of the PID output employed can vary between 0.00 and 1.00 . With the output value at 0.00 , the base aigorithm blower demand will be adjusted downward by $10.0 \%$. With the output value at 1.00 , the base algorithm blower demand will be adjusted upward by $10.0 \%$. With the output value at 0.50 , there will be no adjustment to the base algorithm blower demand. As an option to automatic variation based on generator temperature, the PID output value can be manually set as an operator input. For the RUN operational state, Fig. 15 illustrates the base (PDD output =0.50) algorithm's linear decrease in main air blower demand for currents less than $300 \mathrm{~A}$, consistent with that already discussed for the LOAD state. As the operating currents increase above $300 \mathrm{~A}$, the main air blower demand (using the base algorithm) increases linearly from $72.0 \%$ at $300 \mathrm{~A}$ to $86.9 \%$ at the $759 \mathrm{~A}$ current limit shown in Fig. 15 .

Corresponding RUN operational state bourdaries established by minimum and maximum allowed values of the PID output are also given in the same figure.

\section{Steam Demand}

As shown in the fifth wertical leg of Fig. 2, the stean demand setpoint (Fig. 16) is caloulated from algorithms employing operational state and curent operator inputs. For present purposes, there is steam demand only when the generator is in the LOAD cperational state. Although some stearn may be generated by the steam supply system for oheckout pupposes in other states, the steam demand requirement is primarily for "startap" purposes to provide sufficient water for the intenal fuel reforming processes at low loads (curents less than approximately $250 \mathrm{~A}$ ) during ramp-ip. At higher loads, the generator provides adequate quantities of water as a result of its inherent electrochemical processes. As indicated in Fig. 16, for operating currents less than or equal to $150 \mathrm{~A}$ in the LOAD operational state, the steam demand is fixed at $80 \%$. For greater 


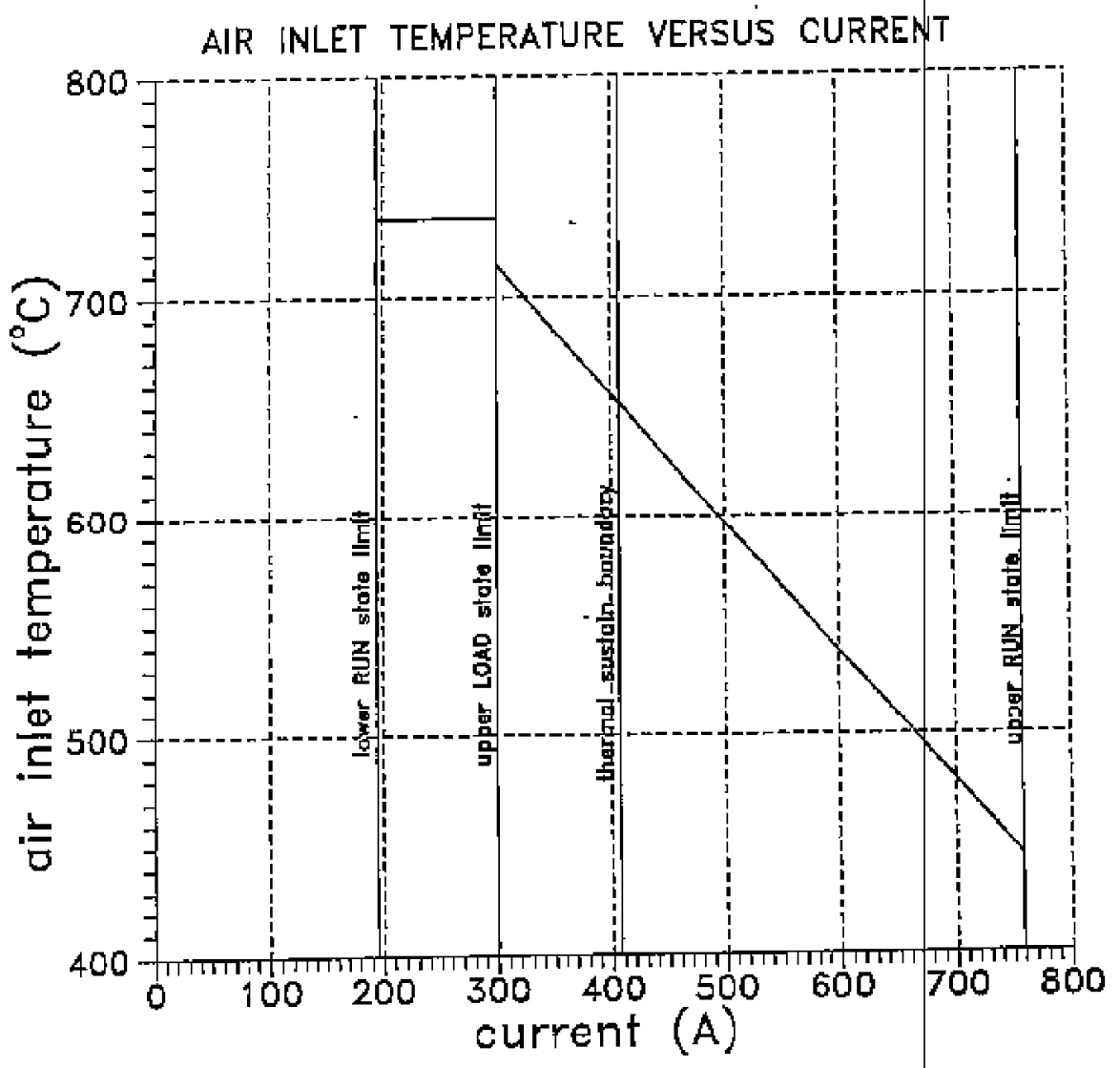

Fig. 14. Air Inlet Temperature Versus Current.

22 (PCD) 


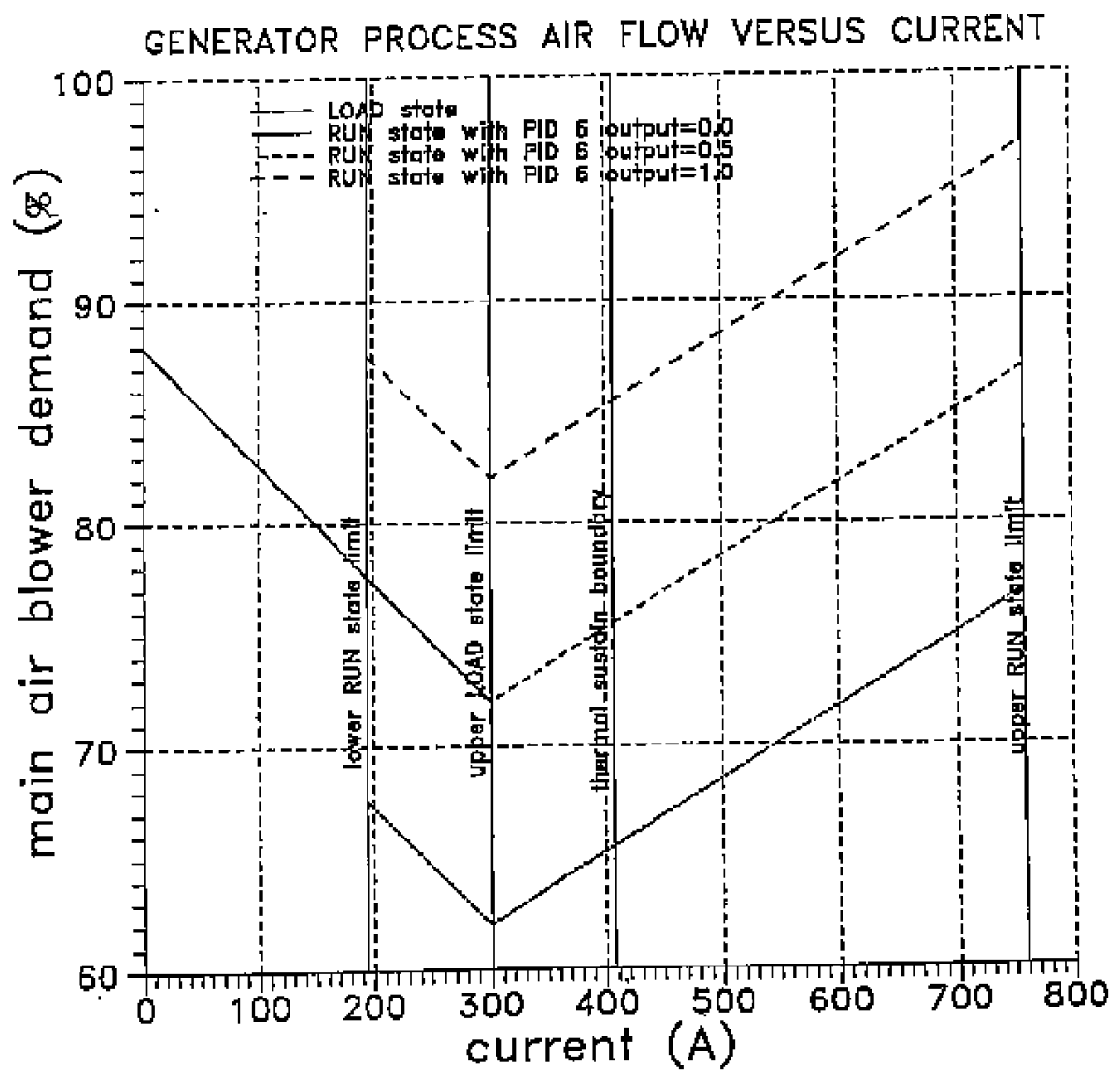

Fig. 15. Generator Process Air Flow Versus Current. 
JUN.24.2018 11: オ7PM UT BATELLE/1113 UNION VALLEY NO.494 P.24/35

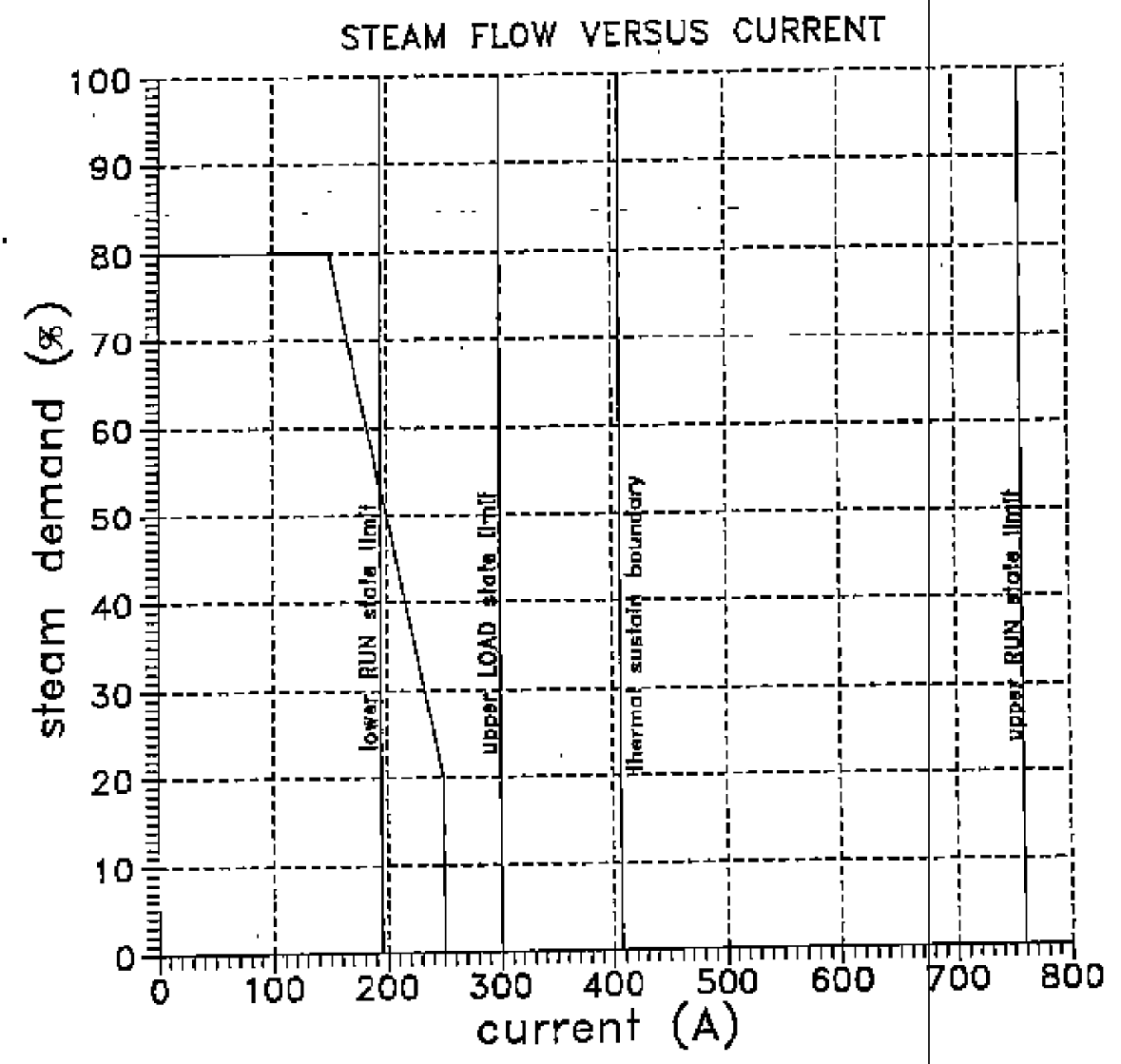

Fig. 16. Steam Flow Versus Current.

24 (RC) 
operating currents in this state, the steam cemand drops linearly with jncreasing current until it reaches $20 \%$ at an operatirg current of $250 \mathrm{~A}$. For operating currents greater than $250 \mathrm{~A}$, the steam demand vanishes.

\section{Warnings}

As shown in the final vertical leg of the flow chart, potential wamings of unallowable conditions are generated from algorithms employing generator temperature, fuel utilization, pperational state, and current operator inputs, as well as segment voltages determized previously in the first leg. For exampie, in the RUN operational state, the allowable generator temperat ire range is 850 to $1050^{\circ} \mathrm{C}$, the allowable current tange is 195 to $759 \mathrm{~A}$, and the minimum allowalle segment voltage is $8.96 \mathrm{~V}$. While in the $\mathrm{LOAD}$ operational state, the mirimum allowyabie generator temperature is $535^{\circ} \mathrm{C}$, the maximum allowable current is $300 \mathrm{~A}$, and the minimum allowable segment voltage is 9.28 V. These valnes are stored in the file LIMITS.DAT and tocessed through the associated NAMELIST assignment in the nodel. Earlier versions also checked, for warning purposes, whethet or not the air flow/fiel flow combination met minimum stoichiometry requirements, depending on the operating current.

\section{Single Operating Poînt Results}

In addition to the parametric exerctses already illustrated, the model described above and listed (with associated input files) following the figures was employed to provide single operating point displays of the relevant variables as indicated by the sample in Fig. 17. Inputs were chosen to represent nominal performance in the RUN operational mode at the themnal sustain boundary with EDB/ELSAM fuel.

\section{Conclusion}

A FORTRAN language-based model has been developed that can assist in exercising and evaluating selected control options for a $100 \mathrm{~kW}$ nominal solid oxide fuel cell generator system. The nodel has been employed to generate parametric relationships for wide ranges of operating conditions.

\section{REFERENCES}

1. Fuel Cells: A Handbook (Revision 3) DOE/METC-94/1006.

2. Training Manual for FDB/ELSAM $100 \mathrm{~kW} \mathrm{SOFC} \mathrm{Generator} \mathrm{System,} \mathrm{Westinghouse} \mathrm{Electrie}$ Corporation, Pittsburgh, Penrsylvania 


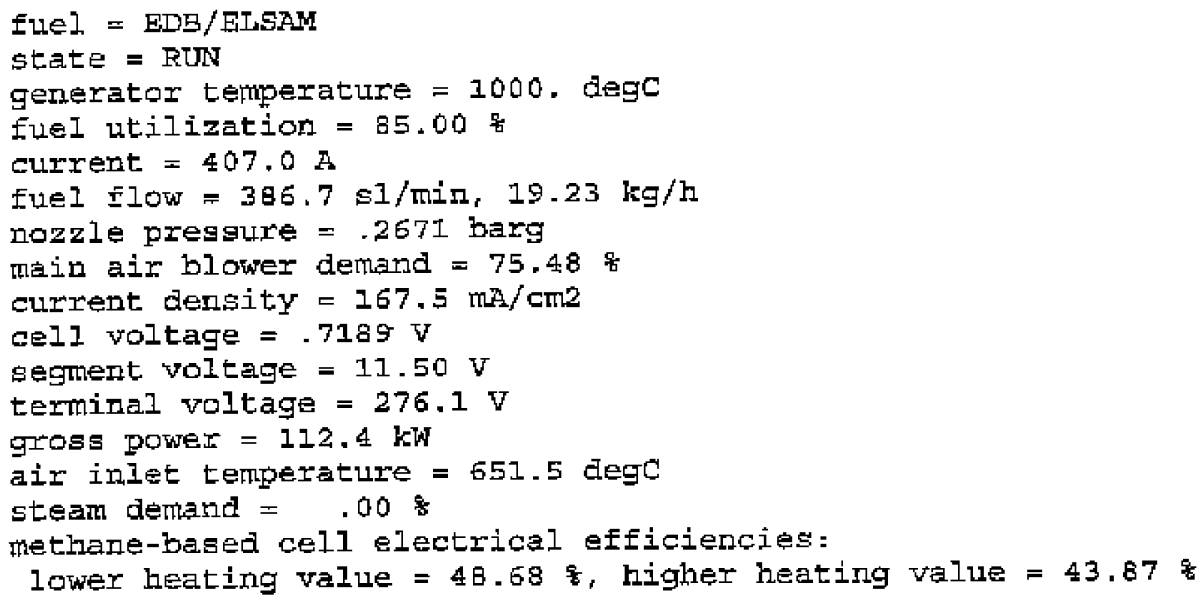

Fig. 17. Sample Single Operating Point Display. 


\section{FORTRAN Listing of Main SOFC Generator ModeI}

C * MODEL FOR 100 \%We SOLID OXIJE FLEL CELL GENERATOR SYSTLM

[natural gal flow, air flow, air temperature, ourrent density, dell voltage, sepment voliage, stack voltage, gross suad power, fouzle pressure, steam tlow

Implicit real $\star b[a-h, 0-z\}$

real*g $\quad$ lk, Itrveht

character atate*4, Euel*9

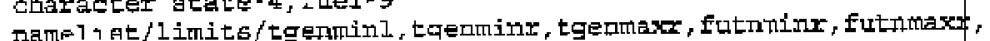

1 bux:maxt, Gursminr, currmaxi, voegminl, trgegmir

nameI s. se/opinpu:/fuel, tgen, frotncpe, amps, state, pidout

$c$ * read state hymit ralues from flle

oger (\{arit=a, filem 'limits , dant')

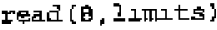

$C$ * read operator inpat values from file

oper (unit=9, Eile= ' opinput . dat ')

read (9, opinput)

0 operatox 1nput (generator temperature; not explictily uged hefe becaule only available charecterizazion data is for 1000 degc;

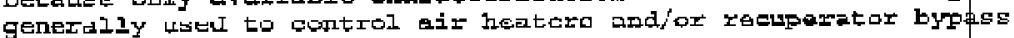
valves

tgen=looodo

* operator ingut [fuel utilization increment in fi]

old allowable rangs: -3 t $=0+5 \%$

new allowable range; $-\mathrm{E}$ - $=0+5$ \%

futtope=0

Euthepo=200

futrepes5do

futilnor-8do

$c$ * operator input (eurrent in amperes)

aाmp $i$ is $=195 \mathrm{do}$

ampmin $=060$

ampmax $=759 \mathrm{do}$

ampmax $=200 \mathrm{dd}$

iحc $=50$

ampinte $=$ (ampmax-ampmin $) / 1 n c$

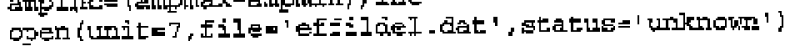

do $100 \quad 1=0,20$

do $200 \quad 1=0,19 n=$

aाpe $=510 \mathrm{~d} 0$

aाmpB $=1000 \mathrm{dO}$

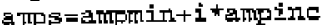

if (i . eqt. 4 ) ampe $=300 \mathrm{do}$

If (i, eq. . inc) amps $=7590$

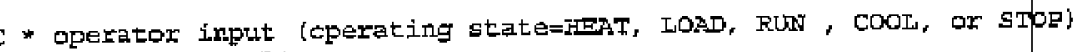




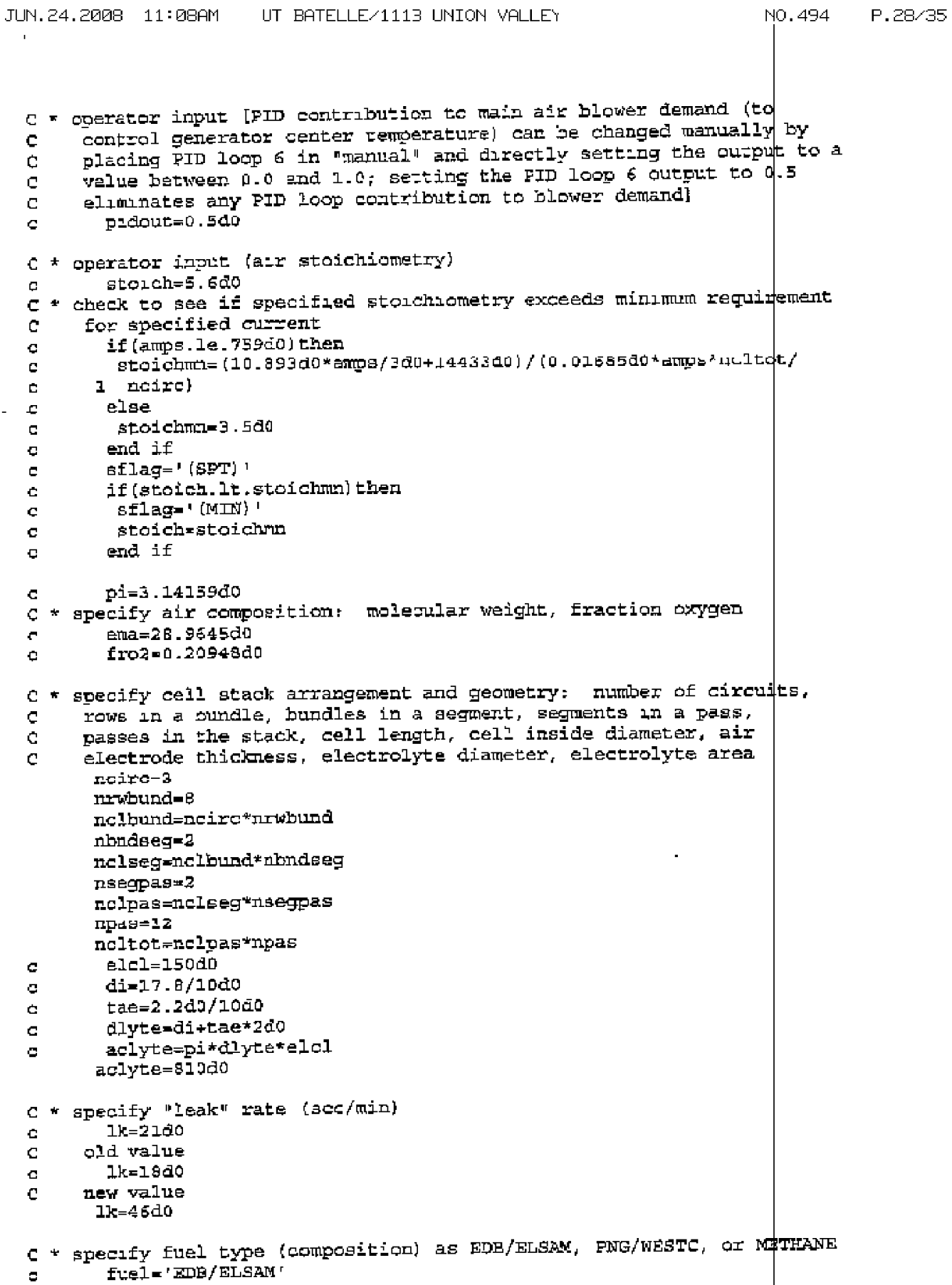

$28(\mathrm{PCn})$ 
c = =UeI $=$ ' DNG/hESTC

$c$ * determine average number of moles of ar and co from each mole of

c mixed bydroesrbon fuel

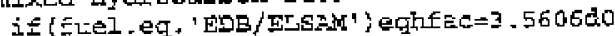

if (Eue?, eg. ' FNG/WESTd' \} eghfaca 4 . 056do

if \{ fuel. Ec. ' WETHANE i \} eghfac= $4 \mathrm{do}$

* determine molecular weight of fuel

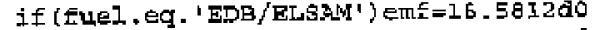

c if (fuel. ed. ' PNG/GESTCl) emf=16. 1220do

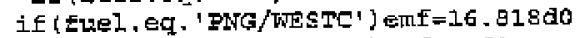

if (fuel, eq. 'METHANA ') emf=1600

$C$ * specify lower and higher heating values for methane $(\mathrm{J} / \mathrm{standard}$

c literl

Ihveh4-3581日do

binch $4=39745 \mathrm{~d} 0$

c * determine fuel utilizetion from bage and increment futbspc=95d0

futpe=futbspatiutrapt

$c$ * determine current dengity ahey=amps/aclyte $1000 d 0 / 300$

* * rese $\mathrm{W}$-J ourve fit to $150-\mathrm{cm}$ cell (558) data (ranges:

(F $0.49<\mathrm{V}<0.75 \mathrm{~V}, \pm 00<\mathrm{J} 2490 \mathrm{~m} / \mathrm{Cm} 2$ ) for $05 \%$ fuel consumption (958 F.U.

$0+21$ secml at 1000 degc, $620 \%$, to deduce cell, gegment, and stack

c veltages

vcel=0.7e579.90-2.83202d-4*zhey-5.92928d-7*zhay*zhay

viegurirwbund*nbriseg*veel

vterm=ncl tot $*$ vel $/ 300$

c * checks for/warns of wallowed operating state

a generrator temperature ohedke.

C LOAD state

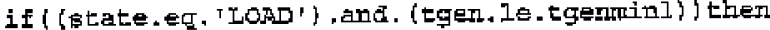
write $(6,10000)$ tgen, atate

10000 format $/$, ' WARNING $1, f 5.0, '$ dege generator temperature ia too 1 low for the ', a4,' atate', /l

end if

C RUN state

if ( (atate .eq. ' fut ') , and. (tgen. le . tgenminr) ) then

write $\{6,10000\}$ tgen, state

end if

if ( (state.eq. 1 gins 1$\}$. and. (tgen.gt . tgenmaxr) ) then

write $\{6,10000\}$ tgen, atate

10004 format $/ /$ " WARWING: ', f5.0, l bege generator temperature is too $h$ 1 igh fọr the ', au, ' gtate', /

end if

c fuel utilizarion increment (pexcent) checks

c RUJ gtate

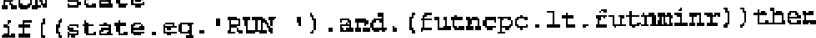
write $[6,10005]$ futrope, state

10005 format $/,{ }^{\prime}$ WRRNDNG:, f5.0, 1 fuel utilization increment is too 1 small for the 1, a 4, ' gtate', $/$

29 (PCD) 


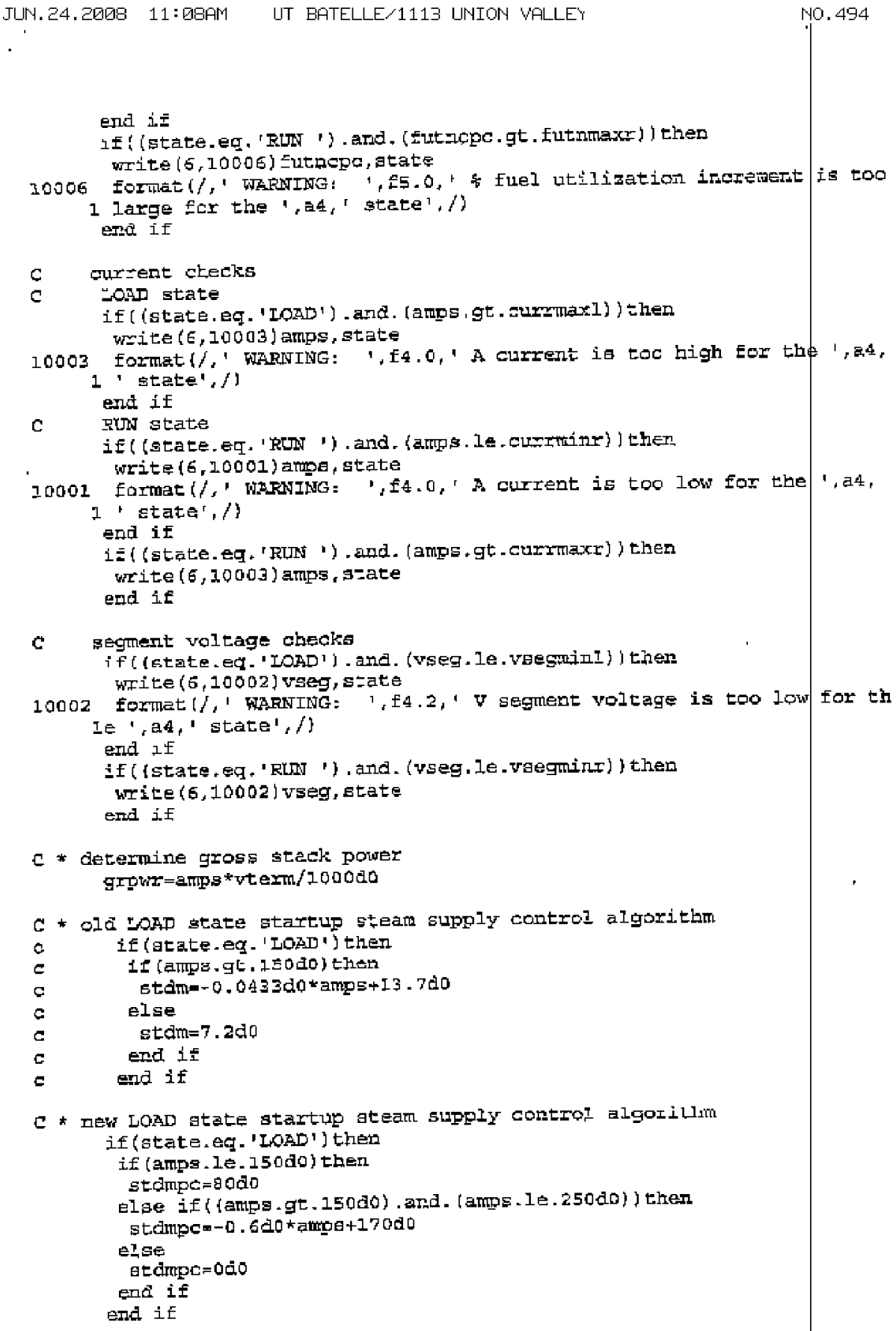




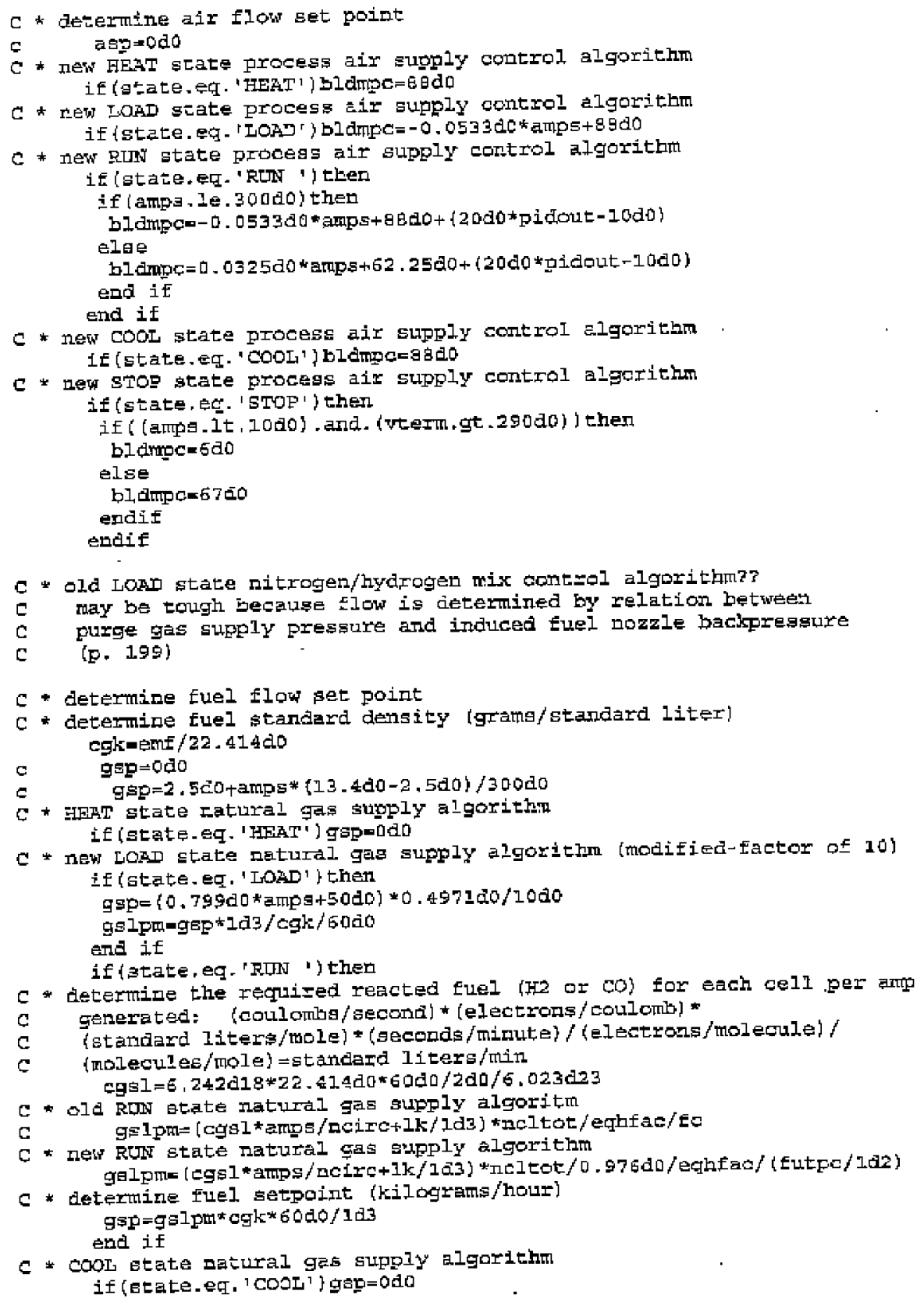




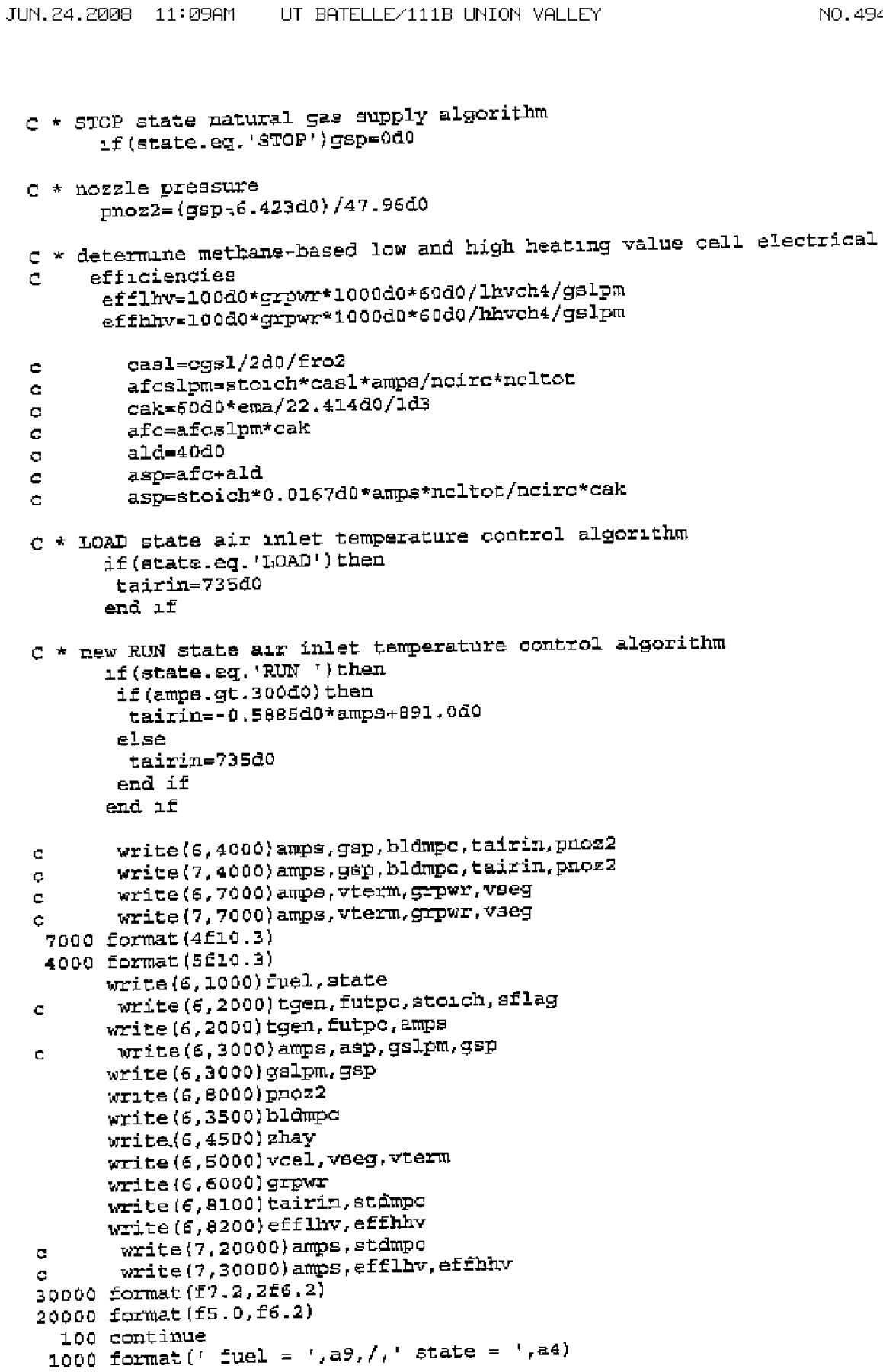

C *TCP stäp patural geg bupply alporithm if (state. eg. 'sTap') gsprodo

C * horale pregsure prozz= $\{g$ gp $-6.423 d 0\} / 47.9600$

c determune methane-based low and high heatung value cell electrical

c effretencier eft1hv=10000* Grom: $1000 d 0 * 6000 / 1 \mathrm{hvch} / \mathrm{galpm}$

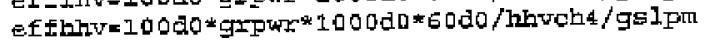

c $\operatorname{cas} 1=\operatorname{cgs} 1 / 2 \mathrm{do} / \mathrm{Ero2}$ afcs.pmastolch* cas 1*ampa/noirc*ncltot

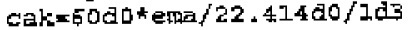
atfc=afics $1 \mathrm{pm}$ cals ald-40do aㅛㅎㅗ=afc+ald asp=stoich*0. 0167do*amps*ncltot/neirc*al:

* Ion state air irlet temperature control algorithm if (atate - eq . ' IrOAD ') then tairin=73540 enti 1 E

$c$ * gew RUN state arr fnlet temperature control algorithm if (state . E4, ' RUN ') then

if (ampe - gt. 300 go then taifin=-0.5385d0*amps+891,000

티오

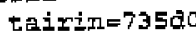

end if

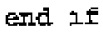

c write $\{6,4000\}$ ampa , gap, bldmpc, ta 4 rin, pnoza 


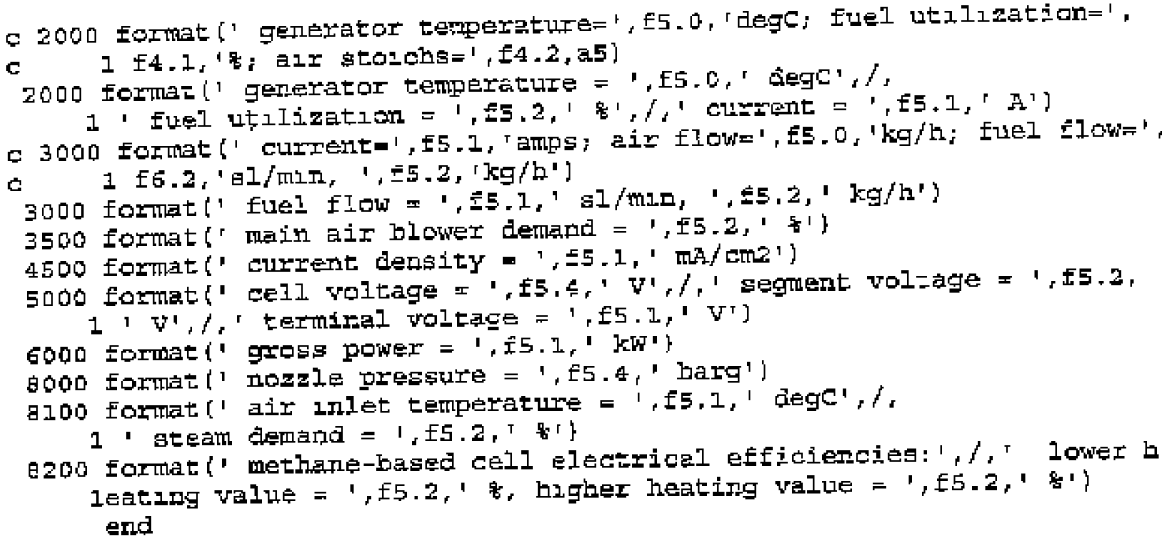


LMITS.DAT File for Use by Main SOFC Generator Model

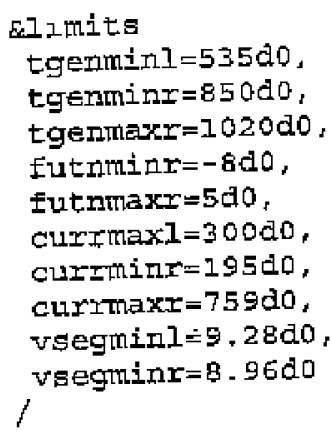


OPINPLT.DAT File for Use by Main SOFC Generator Model

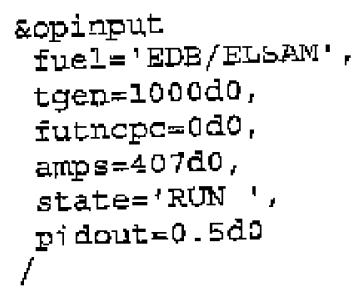

